\title{
Chlorophyllase Activity and Chlorophyll Degradation in Tobacco Chlorophyll Genotypes*
}

by

\author{
S. J. Sheen
}

Department of Plant Pathology, University of Kentucky, Lexington, Kentucky, U.S.A.

and

\section{J. L. Hamilton}

U.S. Department of Agriculture, Science and Education Administration, Lexington, Kentucky, U.S.A.

\section{INTRODUCTION}

Chlorophyll concentration in some tobaccos is partially governed by two pairs of genetic factors, $Y b_{1}$ and $Y b_{2}$ (4). Dark tobaccos are homozygously dominant for these loci, whereas Burleys are homozygously recessive. Quantitative variation of chlorophyll in tobacco affects the concentration of not only nitrogenous compounds but also polyphenols $(8,9,10)$. The latter are one of the precursors of suspected tumor promotors in cigarette smoke (12). Therefore, the genetic regulation of chlorophyll metabolism in tobacco leaf is of importance in the manipulation of leaf chemical constituents for minimizing cigarette smoking and health problems.

Chlorophyll accumulation in chloroplasts is dependent on its rates of biosynthesis and degradation. Chlorophyll degradation begins with the cleavage of the ester linkage between porphyrin and phytol by chlorophyllase. Chlorophyllase activity in the leaf of tobacco chlorophyll-deficient mutants can be indicative of the mode of mutant gene action in chlorophyll biosynthesis or degradation.

The objectives of the present investigation are [1] to determine chlorophyllase activity in a number of chlorophyll-deficient tobaccos and [2] to study the degradation rate of chlorophylls in the same chlorophyll genotypes. The results are discussed in terms of the relationship between chlorophyll metabolism and polyphenol accumulation in tobacco leaf.

\footnotetext{
* Received: 27th April 1982 - accepted: 7th September 1982.
}

\section{MATERIALS AND METHODS}

To elucidate the possible effect of leaf physiological age on chlorophyllase activity, field-grown plants of Ky171 (a dark fire-cured tobacco) and Ky14 (Burley) at flower-bud stage were sampled for leaves from top, middle, and bottom stalk positions. Leaves from the same stalk position of each cultivar were harvested on a row basis and three rows (10-12 plants / row) constituted three replications. Midveins were removed from all leaf samples and the laminae were processed into acetone powder and stored at $-70^{\circ} \mathrm{C}$.

Assay of chlorophyllase activity as conversion of chlorophyll into chlorophyllide was by the method of Terpstra (11) with slight modifications. $0.3 \mathrm{~g}$ of acetone powder was ground in a chilled mortar and pestle with $3 \mathrm{~g}$ of sterile sand and $15 \mathrm{ml}$ of $20 \mathrm{mM}$ Tris- $\mathrm{HCl}$ buffer ( $\mathrm{pH}$ 8.0) containing $7 \mathrm{mM} \mathrm{MgCl}$ and $0.5 \%$ of Triton $\mathrm{X}-100$. The resulting mixture was then centrifuged for $20 \mathrm{~min}$ at $20,000 \mathrm{~g}$ and the enzyme-containing supernatant was filtered through a 0.4 micron microporous filter. The reaction mixtures, containing $1.5 \mathrm{ml}$ of enzyme preparation and $0.2 \mathrm{ml}$ of a methanolic chlorophyll solution $(600-750 \mu \mathrm{g} / \mathrm{ml})$, were incubated at $40^{\circ} \mathrm{C}$ for $2 \mathrm{~h}$ in the dark. To the controls, $6 \mathrm{ml}$ of acetone was added at the beginning of incubation. The same volume of acetone was added to the reaction tube to stop the reaction at the end of incubation. After the addition of $2.5 \mathrm{ml}$ of $2 \% \mathrm{NaCl}$, the mixture was centrifuged for $10 \mathrm{~min}$ at $20,000 \mathrm{~g}$. The concentration of chlorophyll in the supernatant was measured spectrophotometrically at 
$663 \mathrm{~nm}$. The difference between control and reaction mixture as the percent loss of chlorophyll in the control was probably attributable to the 2-hour incubation of chlorophyll in the presence of acetone. Petroleum ether $(10 \mathrm{ml})$ was added to each tube, which was subsequently shaken and allowed to phase-separate. Chlorophyllide formed by chlorophyllase activity was partitioned into the lower acetone layer, whereas the chlorophyll remained in the upper petroleum ether layer, which was discarded. The aqueous acetone layer was measured again at $663 \mathrm{~nm}$. After the adjustment of absorbance in the control for the percent loss of chlorophyll, the difference in absorbance between the control and reaction mixture after petroleum ether partition was calculated in terms of $\mu \mathrm{g}$ of chlorophyll enzymatically metabolized into chlorophyllide. Chlorophyllase activity was expressed as $\mu \mathrm{g}$ chlorophyll metabolized/mg protein $/ \mathrm{h}$ or $\mu \mathrm{g}$ chlorophyll metabolized/g fresh weight/h. Protein concentration in the enzyme preparation was determined by Lowry's method (7) using bovine serum albumin as a standard.

In addition to chlorophyll genes $Y b_{1}$ and $Y b_{2}$, chlorophyll-deficiency genes $P y$ and $y g$ were also studied with regard to chlorophyllase activity. Tobacco cultivars and isogenic lines carrying chlorophyll-deficiency genes, namely NC95, NC95-Py, SC58-yg, Burley 21-yg, Burley 21, and $\mathrm{Ky} 14$, were grown in a greenhouse where environmental conditions were $28^{\circ} \mathrm{C}$ for day and $18^{\circ} \mathrm{C}$ for night with a photoperiod of $14 \mathrm{~h}$ a day. The pedigrees of NC95-Py, SC58-yg, and Burley 21-yg have been previously described (9). When the plants reached the 15-17 leaf stage, middle-stalk leaves of three plants were sampled as one replication and there were four replications for each of the chlorophyll genotypes. The preparation of acetone powder and the assay of chlorophyllase were by the methods described above.

To further examine the rate of chlorophyll degradation in tobacco chlorophyll-deficient genotypes, young leaves about 8-10 inches in length, were detached from greenhouse-grown NC95, NC95-Py, SC58-yg, and Burley 21 at flower-bud stage. Six leaves from each of the above tobaccos were fed with a small volume of $10 \mathrm{mM}$ potassium phosphate buffer $(\mathrm{pH} 7.1)$ containing
$2 \mu \mathrm{C}$ of ${ }^{14} \mathrm{C}$ - $\delta$-aminolevulinic acid $\left[{ }^{14} \mathrm{C}\right.$-ALA (specific activity: $345 \mu \mathrm{C} / \mathrm{mg}$ )]. After about one $\mathrm{h}$, the ${ }^{14} \mathrm{C}$-solution was completely absorbed by the leaf. Radioisotopetreated leaves were then maintained in $10 \mathrm{mM}$ potassium phosphate buffer of the same $\mathrm{pH}$ in a growth chamber where the experimental conditions were $28^{\circ} \mathrm{C}$ and continuous illumination. Leaf discs ( 0.75 inch in diameter) were sampled at time intervals of $2,4,6,8,12,24,48$, and $72 \mathrm{~h}$ after pulse-labelling. Total chlorophyll content, in terms of $\mathrm{mg} / \mathrm{g}$ fresh weight, was determined spectrophotometrically after extraction in $80 \%$ acetone (1). The concentrated acetone extract was spotted onto silica gel TLC plates, which were eluted with a solvent of heptane : diethyl ether : acetone $[6: 3: 2(\mathrm{v} / \mathrm{v} / \mathrm{v})]$. Within $10 \mathrm{~min}$, chlorophyll a and chlorophyll $\mathrm{b}$ had separated into discrete bands, which were subsequently removed and eluted in $0.5 \mathrm{ml}$ of acetone. Concentration of chlorophyll $a$ and chlorophyll $b$ were spectrophotometrically determined by the previously described method. Aliquots of the chlorophyll solution were counted for ${ }^{14} \mathrm{C}$-radioactivity in a Packard automatic Tri-Carb liquid scintillation spectrometer (Model 4322 ) at $6^{\circ} \mathrm{C}$. A chlorophyll dilution series was used to correct the quenching effect.

Data of chlorophyllase activity in leaves of different stalk positions and chlorophyll-deficient genotypes were subjected to statistical analyses and inference according to the corresponding randomized block design of the experiments.

\section{RESULTS AND DISCUSSION}

At flower-bud stage, chlorophyllase in the top, middle, and bottom stalk leaves of Ky171 $\left(\begin{array}{llll}Y b_{1} & Y b_{1} & Y b_{2} & Y b_{2}\end{array}\right)$ metabolized 21.3, 18.1, and $11.7 \mu \mathrm{g}$ chlorophyll $/ \mathrm{mg}$ protein/h, respectively. The difference between top and bottom leaves was statistically significant at the $5 \%$ level of probability. The corresponding activities in Ky14 $\left(y b_{1}\right.$ $y b_{1} \quad y b_{2} \quad y b_{2}$ ) were $14.4,17.5$, and $16.8 \mu \mathrm{g}$ chlorophyll metabolized $/ \mathrm{mg}$ protein $/ \mathrm{h}$, which were not statistically different. Chlorophyll concentration is known to be highest in top leaves and declines toward the lower stalk

Table 1. Chlorophyllase activity In tobacco chlorophyll genotypes *

\begin{tabular}{|c|c|c|c|c|}
\hline \multirow{2}{*}{\multicolumn{2}{|c|}{ Chlorophyll genotype }} & \multicolumn{3}{|c|}{$\begin{array}{l}\text { Activity (amount of chlorophyll converted } \\
\text { to chlorophyllide) expressed in terms of }\end{array}$} \\
\hline & & & $\mu \mathrm{g}$ chlorophyll/mg protein/h & $\mu \mathrm{g}$ chlorophyll/g fresh leaf woight/h \\
\hline NC95 & & & 8.16 & 164.17 \\
\hline NC95-Py & . & & 11.46 & 189.40 \\
\hline SC58-yg & . & . & 9.44 & 218.26 \\
\hline Burley 21-yg & $\ldots$ & & 11.85 & 195.30 \\
\hline Burley 21 & . & & 10.93 & 167.93 \\
\hline Ky14 & . & & 9.83 & 175.58 \\
\hline \multirow{2}{*}{$\begin{array}{l}\text { Least significant } \\
\text { difference }\end{array}$} & $p=0.05$ & & 1.35 & 26.67 \\
\hline & $p=0.01$ & & 1.92 & 37.94 \\
\hline
\end{tabular}

* Middle-stalk leaves of greenhouse plants at 15-17 leaf stage. 
Figure 1. TIme-course changes In chlorophyll concentration and speciflc actlvity after pulse-labelling with ${ }^{14} \mathrm{C}$ aminolevulinic acld in NC95 and NC95-Py.

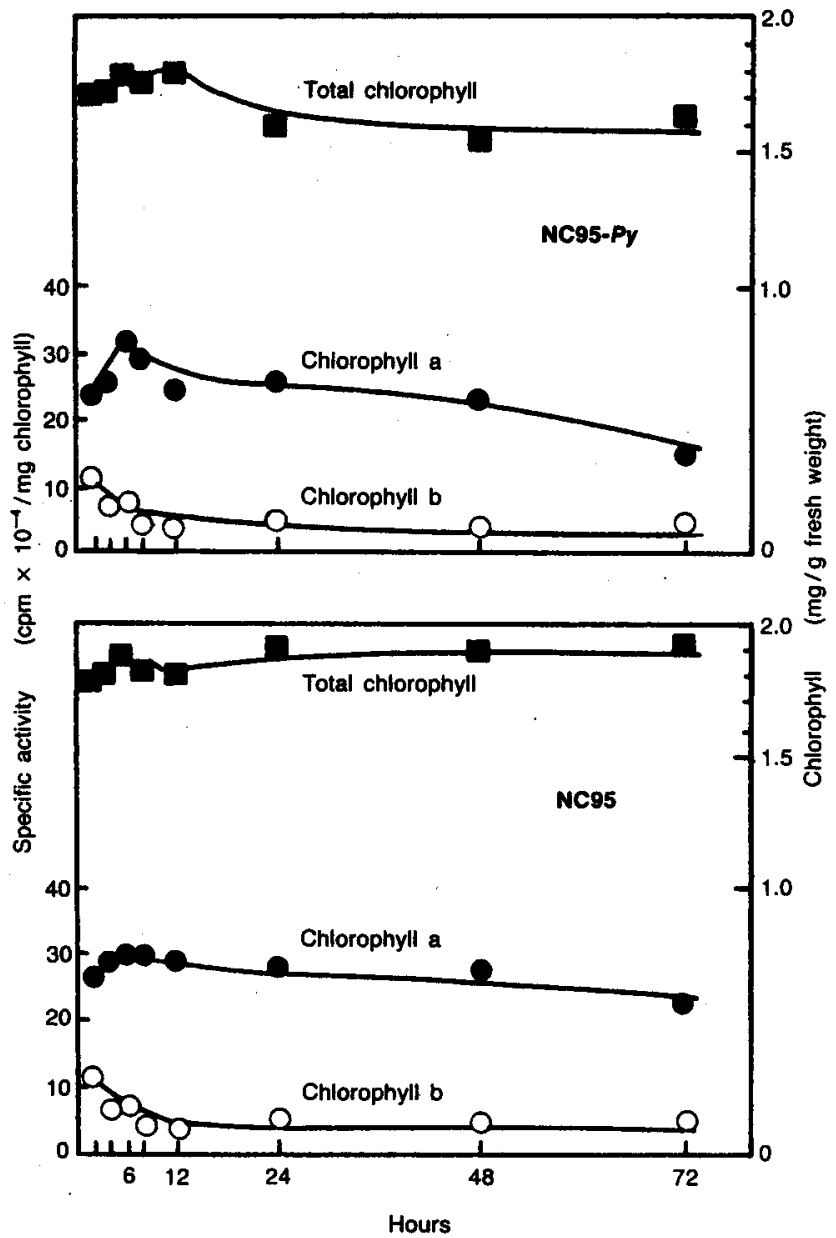

leaves (5). The high chlorophyllase. activity in the top leaves of Ky171 may suggest its role in regulating an excessive accumulation of chlorophyll since this phenomenon is not evident in the chlorophyll-deficient genotype Ky14. One may also point out that the concentration of soluble protein (Fraction I and Fraction II protein) is largest in top leaves and Fraction I protein constitutes more than $50 \%$ of soluble protein (6). The specific activity of chlorophyllase in top leaves would be much greater than in lower stalk leaves if the comparison were made after delineation of Fraction I protein content. When the chlorophyllase activities in leaves of the same stalk positions were compared between the two chlorophyll genotypes, their differences were not statistically significant.

By use of middle-stalk leaves, a number of chlorophylldeficient tobaccos were compared for chlorophyllase activity, which was expressed in terms of protein quantity or fresh leaf weight (Table 1). On the basis of protein quantity, the Py gene in the NC95 background enhanced chlorophyllase activity. However, the increased activity is not statistically significant if chlorophyll loss is calculated on a fresh leaf weight basis instead. This is exactly opposite for the tobaccos carrying the $y g$
Figure 2. Time-course changes in chlorophyll concentration and speciflc activity after pulse-labelling with ${ }^{14} \mathrm{C}$ aminolevulinic acid In Burley 21 and SC58-yg.

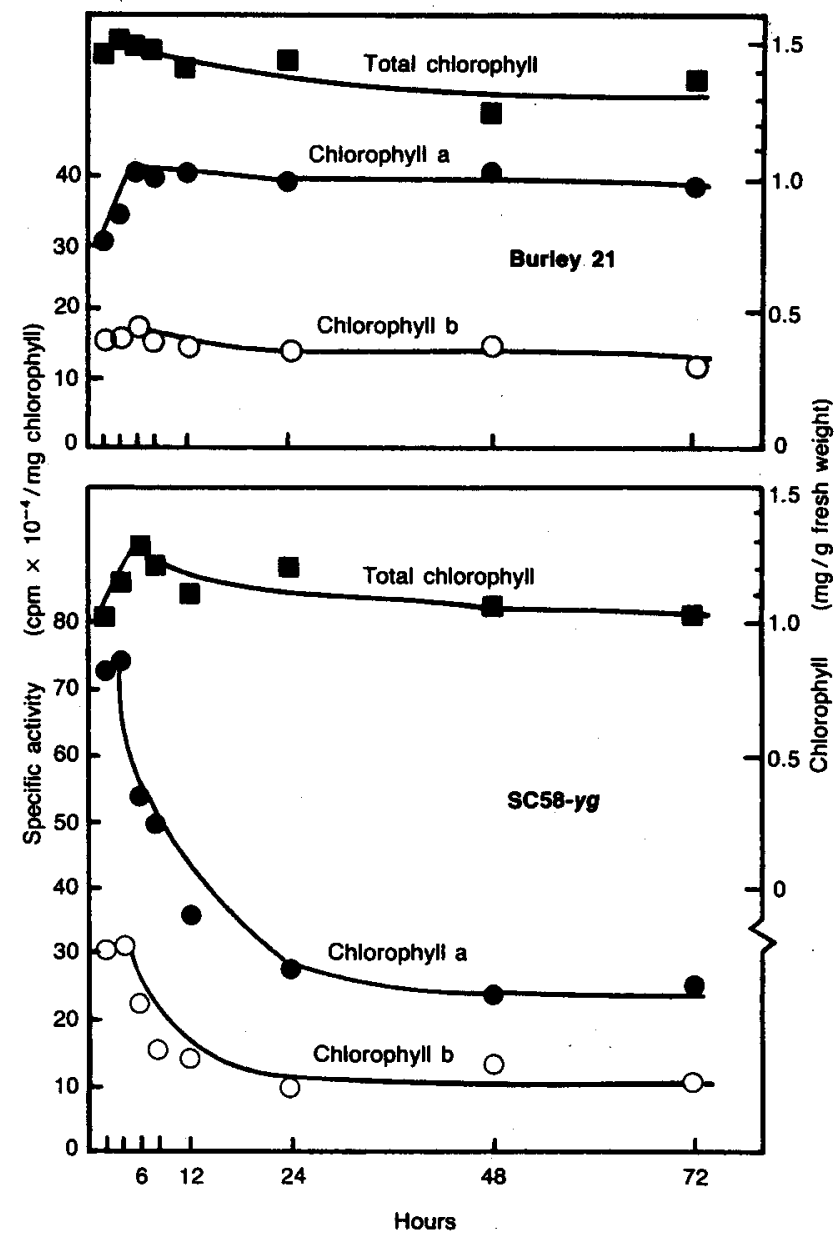

gene. Both SC58-yg and Burley 21-yg showed the highest rate of chlorophyll degradation as measured on the fresh leaf weight basis. On the protein basis, Burley 21-yg had a higher chlorophyllase activity than SC58-yg but it did not differ from the recurrent parent Burley 21 . The present results indicate that the chlorophyll-deficiency genes, $P y$ and $y g$, may be partially correlated with the enhanced activity of chlorophyllase.

The involvement of $P y$ and $y g$ genes in chlorophyll degradation in tobacco is supported by the ${ }^{14} \mathrm{C}$-ALA pulselabelling experiment. Figures 1 and 2 illustrate the timecourse changes of chlorophyll quantity and the specific activity of chlorophyll $a$ and chlorophyll $b$ in four tobacco chlorophyll genotypes. In all cases, the treatment with ALA slightly increased chlorophyll content within the initial several hours, followed by a gradual leveling-off. Within the experimental period, there was no significant decrease in chlorophyll. The initial increase in chlorophyll coincided with an increase in specific activity of chlorophyll a. The specific activity of chlorophyll a and chlorophyll b in NC95 and Burley 21 remained at a constant level during the 72 -hour period. A slight decrease in specific activity, especially chlorophyll a, was evident for NC95-Py. This is consistent 
Figure 3. Chlorophyll and polyphenol blosynthesis in tobacco leaf.

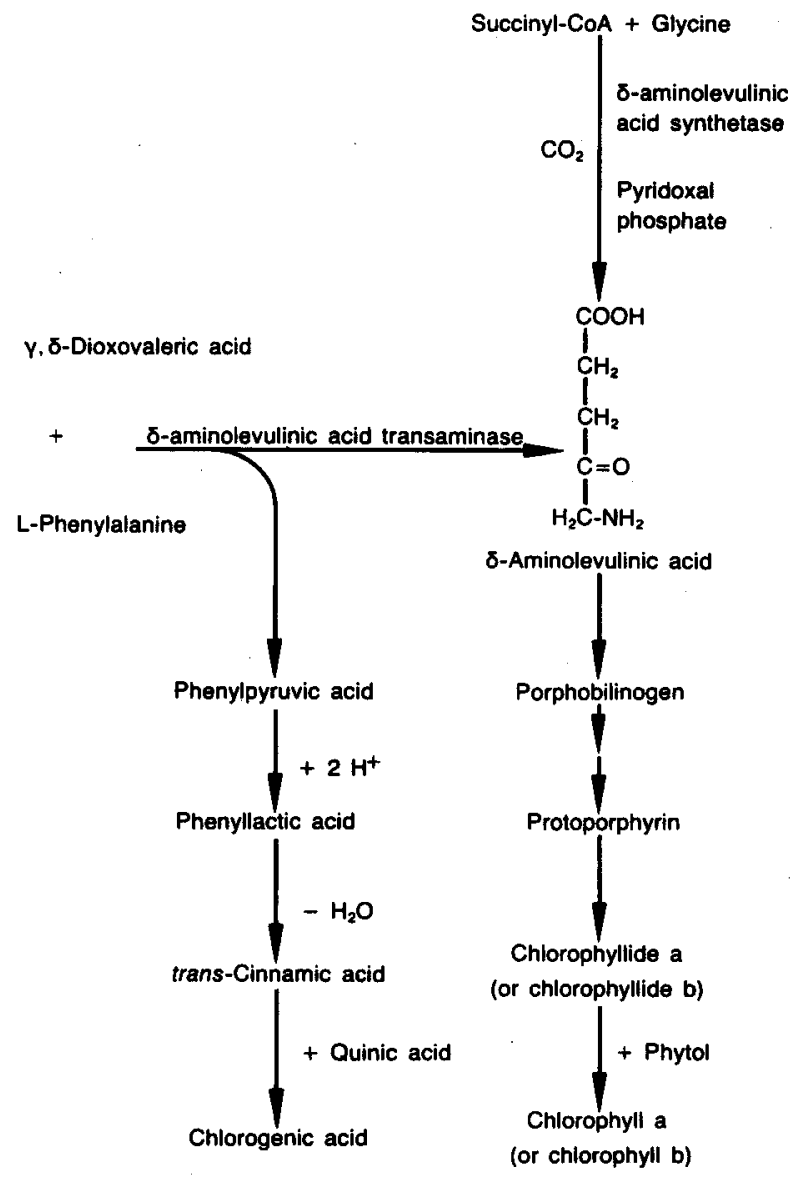

with high chlorophyllase activity in the $P y$ genotype described above. Such a correlation is even more dramatic for SC58-yg, whose specific activity of chlorophyll $a$ and chlorophyll $b$ fell more than one-half within $24 \mathrm{~h}$. The present results strongly suggest that the $y g$ and $P y$ genes exert their effect on chlorophyll deficiency in tobacco leaf through the action of accelerated chlorophyll degradation. It is known that the expression of the $P y$ gene is at leaf maturity (3). One may expect a rapid loss of ${ }^{14} \mathrm{C}$-chlorophyll specific activity if mature leaves of $P y$ line were used in the present experiment.

Chlorophyll biosynthesis in green plants has been reported to involve ALA synthetase; however, information in the literature raised questions in this regard (2). Evidence indicates that ALA is synthesized by ALA transaminase, which catalyzes the transfer of amino groups from certain amino acids to $\gamma, \delta$-dioxovaleric acid. If the ALA transaminase plays a major role in chlorophyll biosynthesis, the positive correlation of chlorophyll and polyphenol quantities in tobacco leaves as reported by Sheen (8) can be explained. A proposed metabolic scheme for chlorophyll and polyphenol biosynthesis in tobacco leaf is given in Figure 2. When ALA transaminase operates in chlorophyll biosynthesis, L-phenylalanine is converted to phenylpyruvic acid. The latter is a precursor of chlorogenic acid. The con- version of ${ }^{14} \mathrm{C}$ - $\mathrm{L}$-phenylalanine into chlorogenic acid and the interference of phenylpyruvic acid on this conversion in tobacco leaf have been experimentally demonstrated (8). Therefore, the more chlorophyll synthesized, the greater the quantity of chlorogenic acid accumulated in the case of dark tobaccos bearing $Y b_{1}$ and $Y b_{2}$ genes. This also explains low chlorophyll and low chlorogenic acid content in Burley $\left(y b_{1} y b_{1} y b_{2} y b_{2}\right)$. As previously pointed out (9), the high polyphenol concentration in the chlorophyll-deficient mutants NC95-Py and SC58-yg cannot be explained by a slow rate of chlorophyll biosynthesis and is possibly attributable to a rapid rate of chlorophyll degradation. The present results offer direct evidence for the regulation of chlorophyll degradation by chlorophyll deficiency genes $P y$ and $y g$ in tobacco. The understanding of chlorophyll and polyphenol metabolism in the leaf of tobacco chlorophyll genotypes could lead to genetic manipulation of tobacco plants toward lowering undesirable leaf constituents so far as cigarette smoking and health problems are concerned.

\section{SUMMARY}

Dark (Ky171) and Burley (Ky14) tobaccos, which differ in chlorophyll genotype at $Y b_{1}$ and $Y b_{2}$ loci, showed no difference in chlorophyllase activity in leaves of the same stalk position. Within a plant, the activity was comparable among three stalk positions in Ky14, whereas the top leaves had higher activity than bottom leaves in Ky171. Since these chlorophyll genes do not modify chlorophyllase activity, these results suggest their mode of action on chlorophyll accumulation is through biosynthesis rather than degradation. In contrast, chlorophyll-deficiency genes $P y$ and $y g$ showed higher chlorophyllase activity than dark and Burley genotypes. This was further substantiated by the loss of ${ }^{14} \mathrm{C}$-chlorophyll specific activity in a pulse-labelling experiment using ${ }^{14} \mathrm{C}-\delta$-aminolevulinic acid as chlorophyll precursor. The mode of action for $P y$ and $y g$ genes on chlorophyll degradation is in concert with polyphenol accumulation in tobacco leaf. A metabolic scheme showing the interrelationship between chlorophyll biosynthesis and polyphenol accumulation is presented.

\section{ZUSAMMENFASSUNG}

Dunkle Tabake (Ky171) und Burley-Tabake (Ky14), die sich genetisch im Bereich der Chlorophyll-Genloci $Y b_{1}$ und $Y b_{2}$ unterscheiden, zeigten unterschiedliche Chlorophyllaseaktivitäten in Blättern des gleichen Blattstandes. Innerhalb einer Pflanze war bei Ky14 die Chlorophyllaseaktivität dreier Blattstände ähnlich, während die oberen Blätter bei Ky171 eine höhere Aktivität des Enzyms zeigten als die unteren. Da die Chlorophyllaseaktivität durch diese Chlorophyll-Gene nicht beeinflußt wird, ist deren Wirkungsweise bei der Chlorophyllakkumulation eher auf dem Weg der Chlorophyllbio- 
synthese als über den Abbau von Chlorophyll anzunehmen. Im Gegensatz hierzu zeigten die ChlorophyllMangelmutanten $P y$ und $y g$ höhere Chlorophyllaseaktivität als dunkle Genotypen und Burley-Genotypen. Dies wurde zusätzlich in einem Puls-Markierungsexperiment mit ${ }^{14} \mathrm{C}-8$-Aminolaevulinsäure als Chlorophyllpräcursor durch den Verlust an spezifischer Aktivität von ${ }^{14} \mathrm{C}$-Chlorophyll erhärtet. Die Wirkungsweise der $P y$ - und $y g$-Gene auf den Chlorophyllabbau geht einher mit der Polyphenolakkumulation im Tabakblatt. Der Zusammenhang zwischen Chlorophyllbiosynthese und Polyphenolakkumulation wird anhand eines Metabolismusschemas erläutert.

\section{RESUMÉ}

Des tabacs bruns (Ky171) et Burley (Ky14) se différenciant génétiquement au niveau des positions des gènes chlorophylliens $Y b_{1}$ et $Y b_{2}$ ne présentent aucune différence concernant les activités de chlorophyllase au sein des feuilles occupant la même position sur la tige. Sur la même plante, on constate une activité analogue sur trois positions de feuille sur la tige en ce qui concerne $\mathrm{Ky} 14$, alors que pour $\mathrm{Ky} 171$, les feuilles du haut révèlent une plus grande activité de cet enzyme que les feuilles du bas. Comme l'activité de la chlorophyllase n'est pas influencée par ces gènes de chlorophylle, ces constatations suggèrent donc que leur mode d'action sur l'accumulation de la chlorophylle s'effectue plutôt par biosynthèse que par dégradation. Contrairement à cela, les génotypes déficients en chlorophylle, $P y$ et $y g$ présentent une plus grande activité de chlorophyllase que ceux des tabacs bruns et Burley. Ceci s'est trouvé confirmé dans le cadre d'une expérience de marquage par impulsion au moyen de l'acide ${ }^{14} \mathrm{C}$ - $\delta$-aminolévulinique en tant que précurseur de la chlorophylle, lors de laquelle on constata la perte de l'activité spécifique de ${ }^{14} \mathrm{C}$-chlorophylle. Le rôle des gènes $P y$ et $y g$ dans la dégradation de la chlorophylle correspond à l'accumulation de polyphénol dans la feuille de tabac. La corrélation existant entre la biosynthèse de la chlorophylle et l'accumulation de polyphénol est illustrée au moyen d'un schéma de métabolisme.

\section{REFERENCES}

1. Arnon, D. I.: Copper enzymes in isolated chloroplasts, Polyphenoloxidase in Beta vulgaris; Plant Physiol. 24 (1949) 1-15.

2. Beale, S. I., and P. A. Castelfranco: The biosynthesis of $\delta$-aminolevulinic acid in higher plants, II. Formation of ${ }^{14} \mathrm{C}$ - $\delta$-aminolevulinic acid from labeled precursors in greening plant tissues; Plant Physiol. 53 (1974) $297 \div 303$.
3. Chaplin, J. F.: Inheritance and possible use of paleyellow character in tobacco; Crop Science 9 (1969) 169-172.

4. Clausen, R. E., and D. A. Cameron: Inheritance in Nicotiana tabacum, XXIII. Duplicate factors for chlorophyll production; Genetics 35 (1950) 4-10.

5. Grunwald, C., J. L. Sims and S. J. Sheen: Effects of nitrogen fertilization and stalk position on chlorophyll, carotenoids and certain lipids of three tobacco genotypes; Can. J. Plant Sci. 57 (1977) 525-535.

6. Lowe, R. H., and S. J. Sheen: Accumulation of soluble proteins and nitrogenous compounds in the leaf of bright and Burley tobaccos during the growing season; Beitr. Tabakforsch. Int. 11 (1982) 161-169.

7. Lowry, O. H., N. J. Rosebrough, A. L. Farr and R. J. Randall: Protein measurement with the Folin phenol reagent; J. Biol. Chem. 193 (1951) 265-275.

8. Sheen, S. J.: Correlation between chlorophyll and chlorogenic acid content in tobacco leaves; Plant Physiol. 52 (1973) 422-426.

9. Sheen, S. J., D. W. DeJong and J. F. Chaplin: Polyphenol accumulation in chlorophyll mutants of tobacco under two cultural practices; Beitr. Tabakforsch. Int. 10 (1979) 57-64.

10. Sheen, S. J., R. H. Lowe and H. R. Burton: Leaf proteins and chemical constituents in tobacco chlorophyll genotypes; Beitr. Tabakforsch. Int. 11 (1982) $170-179$.

11. Terpstra, W.: A study of properties and activity of chlorophyllase in photosynthetic membranes; $\mathrm{Z}$. Pflanzenphysiol. 85 (1977) 139-146.

12. Wynder, E. L., and D. Hoffmann: Tobacco and tobacco smoke, Studies on experimental carcinogenesis; Academic Press, Inc., New York, 1967, p. 317.

\section{Acknowledgements}

This research was supported in part by the U.S. Department of Agriculture (Cooperative Agreement No. 58-7B30-0-188) and in part by the University of Kentucky Tobacco and Health Research Institute (Project No. 24110). This paper is published with the approval of the Director of the Kentucky Agricultural Experiment Station as Journal Series paper No. (82-11-3-88).

\section{Authors' address:}

Department of Plant Pathology,

College of Agriculture,

University of Kentucky,

S-305 Ag. Science Bldg.-North,

Lexington, Kentucky, 40546, U.S.A. 